\title{
A C-TYPE LECTIN FROM Bothrops jararacussu VENOM CAN ADHERE TO EXTRACELLULAR MATRIX PROTEINS AND INDUCE THE ROLLING OF LEUKOCYTES
}

\author{
ELÍFIO-ESPOSITO S. L. (1), HESS P. L. (1), MORENO A. N. (2), LOPES- \\ FERREIRA, M. (3), RICART C. A. O. (4), SOUZA M. V. (4), HASSELMAN- \\ ZIELINSKI F. (1), BECKER J. A. (1), PEREIRA L. F. (1)
}

(1) Laboratory of Animal Physiology, Center of Biological and Health Sciences, Pontifical Catholic University of Paraná (PUCPR), Curitiba, Paraná State, Brazil; (2) Laboratory of Immunology, PUCPR, Curitiba, Paraná State, Brazil; (3) Laboratory of Immunopathology, Butantan Institute, São Paulo, São Paulo State, Brazil; (4) Brazilian Center for Services and Research on Proteins, Department of Cellular Biology, University of Brasília, Brasília, Federal District, Brazil.

\begin{abstract}
Purification of a lectin from Bothrops jararacussu venom (BjcuL) was carried out using agarose-D-galactose affinity gel. MALDI-TOF gave a major signal at $\mathrm{m} / \mathrm{z} 32028$, suggesting the presence of a dimmer composed of two identical subunits. Divalent cations were required for the lectin activity, as complete absence of such ions reduced hemagglutination. BjcuL was more effective at neutral $\mathrm{pH}$ and showed total loss of activity at $\mathrm{pH}$ values below 4.0 and above 9.0. Its agglutinating activity remained stable at $25^{\circ} \mathrm{C}$ until $60 \mathrm{~min}$, but increased when at $35^{\circ} \mathrm{C}$ for at least $15 \mathrm{~min}$. Adhesion assays to extracellular matrix (ECM) glycoproteins showed that the biotinylated lectin $(0.039-5.0 \mu \mathrm{g} / 100 \mu \mathrm{l})$ was capable of binding to fibronectin and vitronectin in a dose-dependent manner. The binding was partially inhibited in the presence of D-galactose. BjcuL $(1.25-10 \mu \mathrm{g} / 30 \mu \mathrm{l})$ potential was investigated for leukocyte rolling and adhesion to endothelial cells in living microvessels using intravital microscopy, which showed that it induced a dose-dependent increase in rolling and adherence of leukocytes, acting directly on endothelial cells of postcapillary venules. The specific association between lectins and their ligands, either on the cell surface or on the ECM, is related to a variety of biological processes. The complementary characterization of BjcuL, shown here, is useful to further understand the venom effects and as a background for future investigation for therapeutic strategies.
\end{abstract}

KEY WORDS: venoms, fibronectins, vitronectin, snakes, intravital microscopy, leukocytes.

CONFLICTS OF INTEREST: There is no conflict.

CORRESPONDENCE TO:

SELENE LOBO ELÍFIO ESPOSITO, Laboratório de Fisiologia Animal, Centro de Ciências Biológicas e da Saúde, Pontifícia Universidade Católica do Paraná (PUCPR), 80215-901, Curitiba, PR, Brasil. Email: selene.e@pucpr.br. 
S. L. Elífio-Esposito et al. A C-TYPE LECTIN FROM Bothrops jararacussu VENOM CAN ADHERE TO EXTRACELLULAR MATRIX PROTEINS AND INDUCE THE ROLLING OF LEUKOCYTES. J. Venom. Anim. Toxins incl. Trop. Dis., 2007, 13, 4, p. 783

\section{INTRODUCTION}

Bothrops species, known as jararacas, are widely found from the South to the Northeast of Brazil and also in Bolivia, Paraguay and Northern Argentina (2). In Brazil, they are responsible for approximately $70 \%$ of the snakebites in humans, which are lethal in $0.3 \%$ cases. Bothrops jararacussu venom is composed of a complex mixture of proteins and bioactive peptides, especially PLA $\mathrm{A}_{2}$, proteases, and C-type lectins $\left(\mathrm{Ca}^{2+}\right.$-dependent), which play different roles in local and systemic injury processes that characterize bothropic envenomation (25).

Lectins are non-enzyme and non-immune proteins capable of binding specifically and non-covalently to carbohydrates (13), rendering them important in cell-cell and cellmolecule recognition processes. Most of the C-type lectins of Viperidae venoms have been described as disulfide-linked dimers of two homologous polypeptides of $\sim 14 \mathrm{kDa}$. They have erythrocyte-agglutinating activity and other properties such as adhesion to plasmatic proteins (28), mitogenic activity on lymphocytes (24), binding to platelet receptors inducing either activation or inhibition of platelet aggregation (22), and reduction of renal flow and glomerular filtration rate (16). The lectin from $B$. jararacussu venom (BjcuL) has been purified and characterized as a C-type galactoside-binding lectin $(4,29)$. Cells from human metastatic breast cancer and human ovarian carcinoma were shown to adhere weakly to BjcuL, reducing the viability of these and other tumor cell lines (5). BjcuL has been reported to induce edema and increase vascular permeability in mouse hind paws, and was recognized by commercial antivenom raised against a pool of Bothrops venoms (29).

The activation of the immune response reported for BjcuL is expected to be due to an interaction of the lectin with glycoconjugates, provoking important specific cellular responses in the formation of innate or acquired immunity. Snakebites are known to cause characteristic local reactions such as severe edema and redness, followed by necrosis (15) and accumulation of leukocytes at the bite site $(8,9)$, which are attributed to metalloproteinases and phospholipases (6). Nevertheless, other components of the venom can also contribute to such stimulation, resulting in an inflammatory response (26).

In the current study, we report an improvement to the BjcuL isolation method and a further characterization of its hemagglutinating properties. We also demonstrated the 
S. L. Elífio-Esposito et al. A C-TYPE LECTIN FROM Bothrops jararacussu VENOM CAN ADHERE TO EXTRACELLULAR MATRIX PROTEINS AND INDUCE THE ROLLING OF LEUKOCYTES. J. Venom. Anim. Toxins incl. Trop. Dis., 2007, 13, 4, p. 784

capacity of the lectin to interact in vitro with fibronectin and vitronectin and to promote in vivo migration of leukocytes.

\section{MATERIALS AND METHODS}

\section{Venom and Reagents}

Bothrops jararacussu venom was obtained from Butantan Institute, São Paulo, Brazil. Fibronectin and vitronectin from human plasma were gifts from Dr. Sílvio Sanches Veiga $(18,32)$.

\section{Lectin Purification}

BjcuL was purified as previously described (4), with modifications: crude venom was suspended in CTBS buffer ( $\mathrm{NaCl} 150 \mathrm{mM}$, Tris- $\left.\mathrm{HCl} 20 \mathrm{mM}, \mathrm{CaCl}_{2} 5 \mathrm{mM}\right), \mathrm{pH} 7.5$, to a final concentration of $20 \mathrm{mg} / \mathrm{ml}$ and applied to a $5 \mathrm{ml}$ agarose-D-galactose column (Pierce, USA). After $4 \mathrm{~h}$ agitation at $4^{\circ} \mathrm{C}$, elution was carried out with the same buffer. The retained material was eluted with $100 \mathrm{mM}$ lactose in the buffer and this fraction was extensively dialyzed against distilled water for complete removal of the sugar. Carbohydrate content in the dialysis water was tested by the method of Dubois et al. (7). Protein concentrations were determined (21) using bovine serum albumin as standard.

\section{Sodium Dodecyl Sulphate-Polyacrylamide Gel Electrophoresis (SDS-PAGE)}

Electrophoresis was performed (20) on 20\% SDS-polyacrylamide gels $(12 X 10 \mathrm{~cm}$, $0.75 \mathrm{~mm}$ thick), under natural and reducing conditions, with $\beta$-mercaptoethanol. A low molecular weight protein kit was used for standardization (Gibco BRL, USA).

\section{MALDI-TOF Spectrometry}

BjcuL was analyzed by MALDI-TOFy using a Reflex IV mass spectrometer (Bruker Daltonics, Karlsruhe, Germany). The sample was applied onto the target plate using the dry droplet technique, in which $1 \mu$ l sample containing $1 \mu \mathrm{g}$ total protein in $0.1 \%$ trifluoroacetic acid (TFA) was mixed with $1 \mu \mathrm{l}$ matrix $(20 \mathrm{mg} / \mathrm{ml}$ sinapinic acid in $0.1 \%$ TFA, $40 \%$ acetonitrile). The sample was allowed to dry and was then washed twice with $5 \mu \mathrm{L}$ of $0.1 \%$ aq. TFA. The spectrum was obtained in linear mode. 
S. L. Elifio-Esposito et al. A C-TYPE LECTIN FROM Bothrops jararacussu VENOM CAN ADHERE TO EXTRACELLULAR MATRIX PROTEINS AND INDUCE THE ROLLING OF LEUKOCYTES. J. Venom. Anim. Toxins incl. Trop. Dis., 2007, 13, 4, p. 785

\section{Hemagglutination Assays}

Agglutination assays were conducted using untreated human erythrocytes. These were washed three times with $0.9 \%$ aq. $\mathrm{NaCl}$ and suspended at a concentration of $1.0 \times 10^{7} \mathrm{cells} / \mathrm{ml}$. Tests were carried out in hemolysis tubes by titration of the lectin $(50 \mu \mathrm{g} / \mathrm{ml})$ in $150 \mathrm{mM}$ aq. $\mathrm{NaCl}$, followed by addition of the erythrocyte suspension at a volume corresponding to $10 \%$ of that of the lectin solution. Tubes were gently shaken and incubated at $22^{\circ} \mathrm{C}$ for $1 \mathrm{~h}$. Agglutination was evaluated by the naked eye and graded from 0 (negative) to +4 . The hemagglutination titer is calculated as the reciprocal of the multiple of the dilution giving a positive reaction. Controls for all titrations were prepared by substituting lectin for saline solution. The test for divalent cation requirements was carried out as described above; however, $\mathrm{CaCl}_{2}, \mathrm{MgCl}_{2}$ or $\mathrm{MnCl}_{2}$ alone, at indicated concentrations, were added to $\mathrm{NaCl}$ solution. The $\mathrm{pH}$ range within which the glycoprotein exhibits optimum binding to human erythrocytes was determined by titration of the lectin samples in the following buffers: $50 \mathrm{mM}$ sodium citrate-phosphate $(\mathrm{pH} 3.0-5.0), 50 \mathrm{mM}$ sodium acetate $(\mathrm{pH} 4.0-5.0), 50 \mathrm{mM}$ sodium phosphate $(\mathrm{pH} 6.0-7.5)$ and $50 \mathrm{mM}$ Tris- $\mathrm{HCl}(\mathrm{pH} 8.0-9.0)$, all containing $150 \mathrm{mM} \mathrm{NaCl}$ and $20 \mathrm{mM} \mathrm{CaCl}_{2}$. The lectin thermal stability was estimated by incubating the samples at increasing temperatures up to $80^{\circ} \mathrm{C}$ for $15,30,45$ and $60 \mathrm{~min}$, followed by spontaneous cooling to $25^{\circ} \mathrm{C}$ and titration with saline solution $(150 \mathrm{mM} \mathrm{NaCl} / 20 \mathrm{mM}$ $\mathrm{CaCl}_{2}$ ).

\section{ECM Protein Adhesion Assay}

BjcuL $(2 \mathrm{mg})$ was diluted in $50 \mathrm{mM} \mathrm{NaCO}_{3}(1 \mathrm{ml}), \mathrm{pH} 8.6$, and mixed with $74 \mu \mathrm{l}$ of SulfoNHS-LC-biotin (Pierce Chemical Co., Rockford, IL, USA) solution $(1 \mathrm{mg} / \mathrm{ml})$. After 40min incubation in the dark, the mixture was ultrafiltrated through a Centricon YM3 membrane (Amicon Division, W.R. Grace \& Co., Beverly, MA). For adhesion assays, wells of 96-well flat bottom plates (MaxiSorp, FluoroNunc, Roskilde, Denmark) were coated with $100 \mu \mathrm{l}$ of fibronectin or vitronectin $(0.25 \mu \mathrm{g} /$ well $)$ in $0.1 \mathrm{M} \mathrm{NaHCO} / \mathrm{Na}_{2} \mathrm{CO}_{3}$, $\mathrm{pH} 9.5$, overnight at $4^{\circ} \mathrm{C}$. Excess protein was removed by washing the wells three times with phosphate buffered saline (PBS) containing 0.05\% Tween-20 (washing buffer), followed by blocking with $10 \%$ fetal bovine serum (FBS) in PBS for $1 \mathrm{~h}$. After 
S. L. Elífio-Esposito et al. A C-TYPE LECTIN FROM Bothrops jararacussu VENOM CAN ADHERE TO EXTRACELLULAR MATRIX PROTEINS AND INDUCE THE ROLLING OF LEUKOCYTES. J. Venom. Anim. Toxins incl. Trop. Dis., 2007, 13, 4, p. 786

incubation, wells were washed $(3 X)$ and biotinylated lectin was added (2.5$0.04 \mu \mathrm{g} /$ well). For a negative control, lectin was replaced by the washing buffer; for a positive control, $\mathrm{KM}+$ (a lectin isolated from Artocarpus integrifolia seeds) was used $(10 \mu \mathrm{g} /$ well). After $2 \mathrm{~h}$ incubation, wells were washed $(5 \mathrm{X})$ followed by $30 \mathrm{~min}$ incubation with avidin-peroxidase $(0.4 \mu \mathrm{g} /$ well). Then, wells were washed again $(7 \mathrm{X})$, and lectin adhesion to immobilized proteins was revealed after $30 \mathrm{~min}$ incubation with benzenediamine $O$-phenylenediamine substrate, $50 \mu \mathrm{l} /$ well, in the dark. The reaction was stopped by addition of $2 \mathrm{M} \mathrm{H}_{2} \mathrm{SO}_{4}(50 \mu \mathrm{l} /$ well) and colorimetrically quantified by absorbance reading at 490nm on a plate reader (Tecan, Sunrise Remote, Austria). For inhibition assays, BjcuL was preincubated with different concentrations of carbohydrates for $1 \mathrm{~h}$ at room temperature and allowed to adhere to immobilized proteins. Results were expressed as the mean \pm standard deviation. Statistical analyses were carried out using ANOVA and Tukey test.

\section{Microcirculatory Alterations}

Observations of leukocyte interactions in the mouse cremaster muscle venules were performed as previously described $(27,31)$. Mice were anesthetized with an ip injection of sodium pentobarbital $(50 \mathrm{mg} / \mathrm{kg}$ body weight), placed on a water-heated bed (at $37^{\circ} \mathrm{C}$ ), and their cremaster muscle was exposed for topical application of lectin $(1.25,2.5,5$ and $10 \mu \mathrm{g} / 30 \mu \mathrm{l})$. Control experiments were performed by applying $30 \mu$ I PBS under otherwise identical conditions. Muscle preparations were observed in a triocular microscope (Axioskope, Carl-Zeiss) and analyzed with an image analyzer software (KS 300, Kontron). Images were obtained using an X10/025 longitudinal distance objective/numeric aperture and 1.6 optovar. A five-minute observation period was recorded before the lectin application in order to analyze the dynamics in the control tissue. Experiments were carried out for up to $30 \mathrm{~min}$. A $5 \mu \mathrm{g}$ dose was used to evaluate rolling and adherent leukocytes at 10, 20, and $30 \mathrm{~min}$.

\section{RESULTS}

\section{Purification and Characterization of $B$. jararacussu Venom Lectin}

The purification procedure for BjcuL was monitored using agglutination assays with human erythrocytes (type A) and SDS-PAGE analyses. Total isolation was achieved 
S. L. Elífio-Esposito et al. A C-TYPE LECTIN FROM Bothrops jararacussu VENOM CAN ADHERE TO EXTRACELLULAR MATRIX PROTEINS AND INDUCE THE ROLLING OF LEUKOCYTES. J. Venom. Anim. Toxins incl. Trop. Dis., 2007, 13, 4, p. 787

with a single chromatoghaphic step, using a column of agarose-D-galactose affinity gel, eluted with 100mM lactose in CTBS (Figure 1A). As shown in Table 1, in a typical purification procedure from $100 \mathrm{mg}$ crude venom, $\sim 5 \mathrm{mg}$ of purified lectin was obtained with increased hemagglutinating activity. It migrated on Coomassie-stained SDS-PAGE gels as a single band of $\sim 15 \mathrm{kDa}$ or $\sim 30 \mathrm{kDa}$ in the presence or absence of 2-mercaptoethanol, respectively (Figure 1B). This is consistent with mass spectrometry results, which showed a major ion of 32028Da and minor ones of $\sim 16000$ and 64000Da (Figure 1C), suggesting that the lectin is mainly a dimer composed of two identical subunits linked by cystine bonds, but other aggregate levels are possible.

Table 1. Properties of the fractions obtained during lectin purification (from $100 \mathrm{mg}$ of crude venom).

\begin{tabular}{|c|c|c|c|c|c|c|}
\hline Fraction & $\begin{array}{l}\text { Volume } \\
\text { (ml) }\end{array}$ & $\begin{array}{c}\text { Protein } \\
\text { concentration } \\
\left(\mathrm{mg} \cdot \mathrm{ml}^{-1}\right)\end{array}$ & $\begin{array}{l}\text { Total } \\
\text { protein } \\
\text { (mg) }\end{array}$ & $\begin{array}{c}\text { Agglutination } \\
\text { titer }^{a}\end{array}$ & $\begin{array}{c}\text { Total } \\
\text { activity } \\
(\mathrm{AU})^{\mathrm{b}}\end{array}$ & $\begin{array}{c}\text { Specific } \\
\text { activity } \\
(\mathrm{AU} / \mathrm{mg})^{\mathrm{C}}\end{array}$ \\
\hline Crude venom & 5 & 20 & 100 & 4 & 20 & 0.2 \\
\hline $\begin{array}{l}\text { Purified } \\
\text { fraction }\end{array}$ & 28 & 0.18 & 5.2 & 16 & 448 & 86 \\
\hline
\end{tabular}

${ }^{a}$ Titer is recorded as the reciprocal highest dilution showing a +4 agglutination degree.

${ }^{\mathrm{b}}$ Volume $\mathrm{X}$ agglutination titer

${ }^{c} \mathrm{AU} /$ total protein

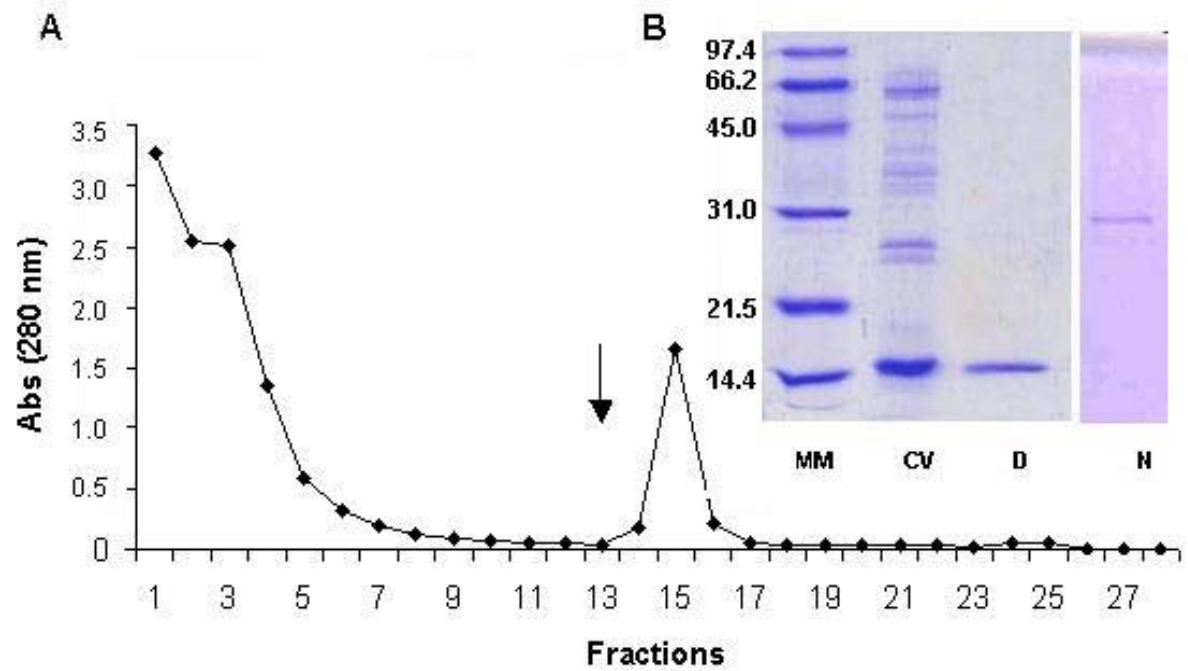




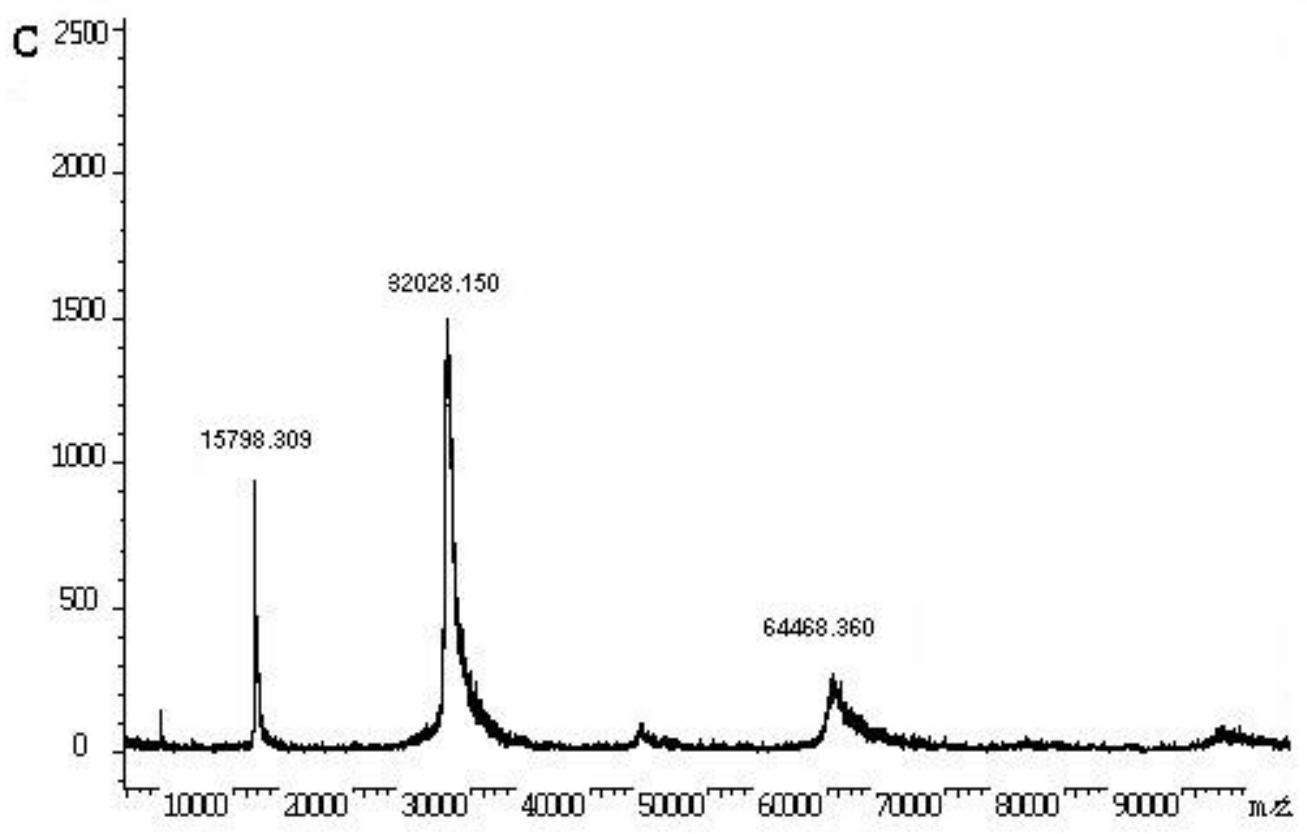

Figure 1. Lectin purification. (A) Elution profile of crude venom (100mg) on agarose-Dgalactose column $(5 \mathrm{ml})$, collected in $2 \mathrm{ml}$ fractions. Total proteins were eluted with CTBS, $\mathrm{pH}$ 7.5 , and adsorbed fraction with $100 \mathrm{mM}$ lactose solution in the same buffer (indicated by the arrow). (B) SDS-PAGE of the purified fraction. MM: molecular mass marker proteins ( $\mathrm{kDa})$; $\mathrm{CV}$ : Bothrops jararacussu crude venom; D: denaturant conditions in the presence of 2mercaptoethanol; $\mathrm{N}$ : natural conditions. (C) MALDI-TOF mass spectrometry of $B$. jararacussu lectin. The sample was applied using the dry droplet technique. The spectrum was acquired in linear mode.

\section{Hemagglutination Characterization}

BjcuL agglutinated all types of human erythrocytes, but showed a high preference for type B over type A (data not shown), which indicates blood-group specificity, depending on the cell-surface carbohydrate moieties. Divalent cations such as $\mathrm{Ca}^{2+}$, $\mathrm{Mg}^{2+}, \mathrm{Mn}^{2+}$ were required for BjcuL activity, as their complete absence reduced hemagglutination (Figure 2). The best results were obtained with $\mathrm{Ca}^{2+}$ and $\mathrm{Mg}^{2+}$ at 40 and $50 \mathrm{mM}$, respectively. The lectin was more effective at a neutral $\mathrm{pH}$ range, showing a gradual increase in activity from $\mathrm{pH} 5.0$ to 7.0, 7.5 then decreasing up to $\mathrm{pH}$ 8.5. It showed total loss of activity when assayed at $\mathrm{pH}$ values below 4.0 and above 9.0. Agglutinating activity remained stable up to $60 \mathrm{~min}$ at $25^{\circ} \mathrm{C}$, but increased when the lectin was left at $35^{\circ} \mathrm{C}$ for at least $15 \mathrm{~min}$. Its activity also remained stable from 40 to $50^{\circ} \mathrm{C}$ up to $30 \mathrm{~min}$, then drastically reduced. At $70^{\circ} \mathrm{C}$, the lectin was completely inactivated (Figure 2). 
S. L. Elífio-Esposito et al. A C-TYPE LECTIN FROM Bothrops jararacussu VENOM CAN ADHERE TO EXTRACELLULAR MATRIX PROTEINS AND INDUCE THE ROLLING OF LEUKOCYTES. J. Venom. Anim. Toxins incl. Trop. Dis., 2007, 13, 4, p. 789
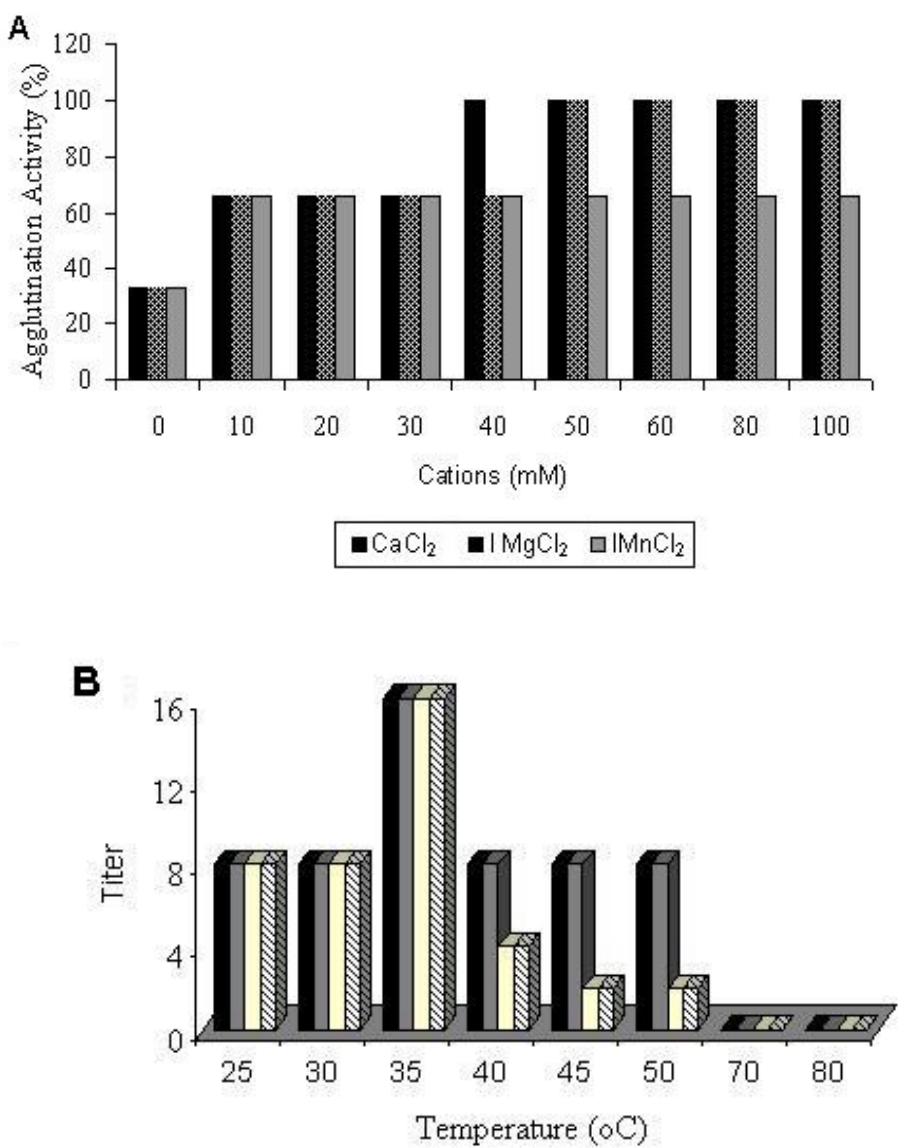

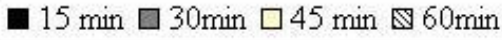

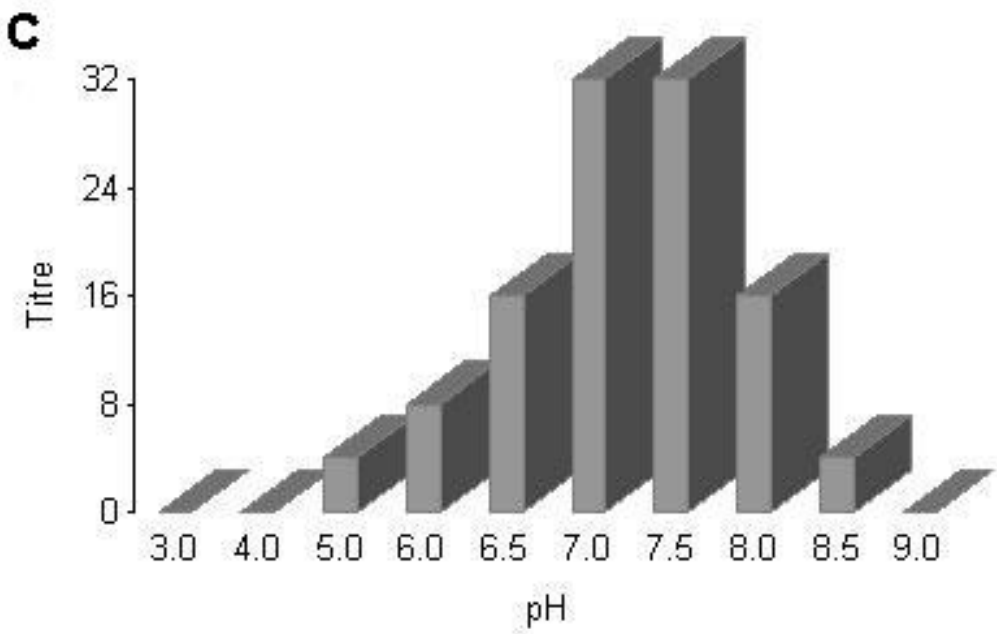

Figure 2. Effect of divalent cations (A), temperature (B) and pH (C) on Bothrops jararacussu lectin hemagglutinating activity. Thermal stability was verified by maintaining the lectin solution at different temperatures for increasing exposure times. The effect of $\mathrm{pH}$ was measured by incubating the lectin solution with different $\mathrm{pH}$-buffered solutions for $1 \mathrm{~h}$ at $25^{\circ} \mathrm{C}$. All procedures were followed by activity assays under standard conditions. 
S. L. Elífio-Esposito et al. A C-TYPE LECTIN FROM Bothrops jararacussu VENOM CAN ADHERE TO EXTRACELLULAR MATRIX PROTEINS AND INDUCE THE ROLLING OF LEUKOCYTES. J. Venom. Anim. Toxins incl. Trop. Dis., 2007, 13, 4, p. 790

\section{Adhesion Assays}

Adhesion assays to ECM glycoproteins showed that the biotinylated lectin (0.039$5.0 \mu \mathrm{g} / 100 \mu \mathrm{l})$ was capable of binding, in a dose-dependent manner, to fibronectin and vitronectin (Figure 3A). Binding was partially inhibited in the presence of D-galactose. Mannose, up to a concentration of $100 \mathrm{mM}$, did not inhibit BjcuL binding to the glycoproteins (Figure 3B).
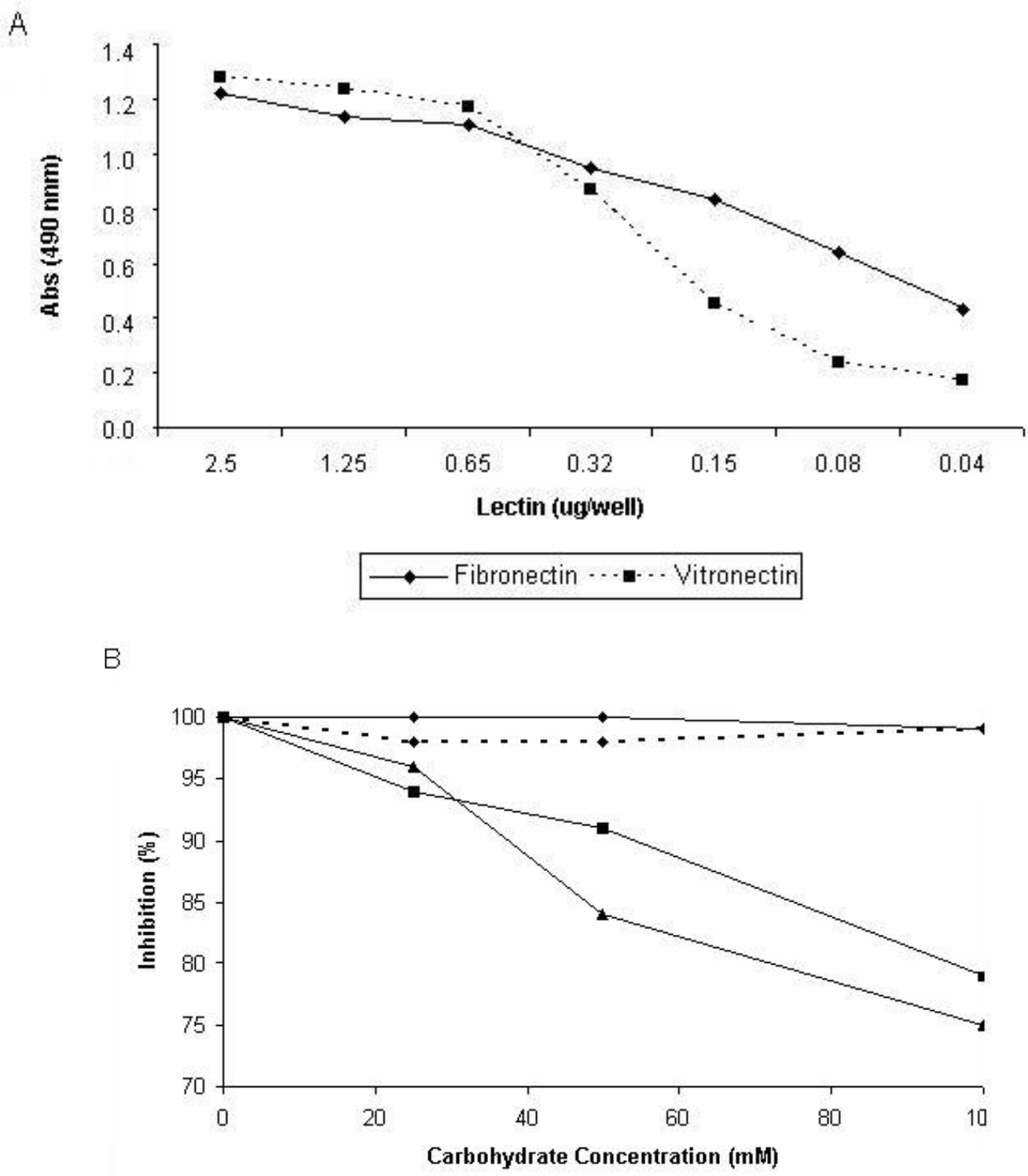

$\longrightarrow-$ Fibro+Man - -^- - Vitro+Man $\longrightarrow$ Fibro+Gal $\longrightarrow-$ Vitro+Gal

Figure 3. Adhesion of Bothrops jararacussu venom lectin to extracellular matrix proteins, fibronectin and vitronectin (A), and the interference of galactose (Gal) and mannose (Man) at different concentrations (B). Negative control in the absence of lectin. 
S. L. Elífio-Esposito et al. A C-TYPE LECTIN FROM Bothrops jararacussu VENOM CAN ADHERE TO EXTRACELLULAR MATRIX PROTEINS AND INDUCE THE ROLLING OF LEUKOCYTES. J. Venom. Anim. Toxins incl. Trop. Dis., 2007, 13, 4, p. 791

\section{Intravital Microscopy}

To investigate BjcuL potential for leukocyte rolling and adhesion to endothelial cells under the conditions prevailing in living microvessels, the cremaster muscle of mice was exposed for topical application of lectin $(1.25,2.5,5$, and $10 \mu \mathrm{g} / 30 \mu \mathrm{l})$ and evaluated after $30 \mathrm{~min}$. A few rolling leukocytes (velocity $>30 \mu \mathrm{m} / \mathrm{s}$ ), but essentially no firmly adherent cells, were observed in the postcapillary venules of control mice (black bars, Figure 4). Numerous leukocytes interacted with the endothelium in the cremaster of BjcuL-treated mice (Figure 4A), and the vast majority of these cells adhered firmly to the vessel walls after lectin application. The increase in rolling and adherent leukocytes, induced by lectin, was dose-responsive (Figure 4B). The average number of rolling and adherent leukocytes was higher in the lectin group than in the control group until 30min (Figure 5). Analysis of the recorded videotapes did not show any evidence of accumulated platelets in postcapillary venules of cremaster muscle of BjcuL or PBS-treated mice (data not shown).

(A)

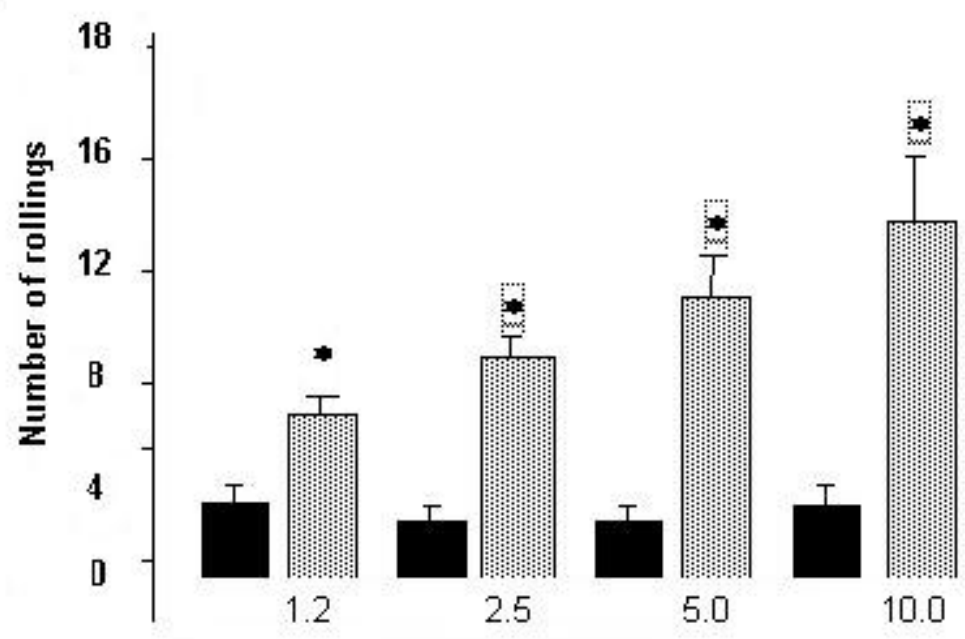

Topical application

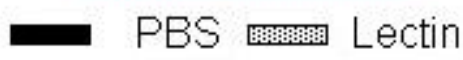


(B)

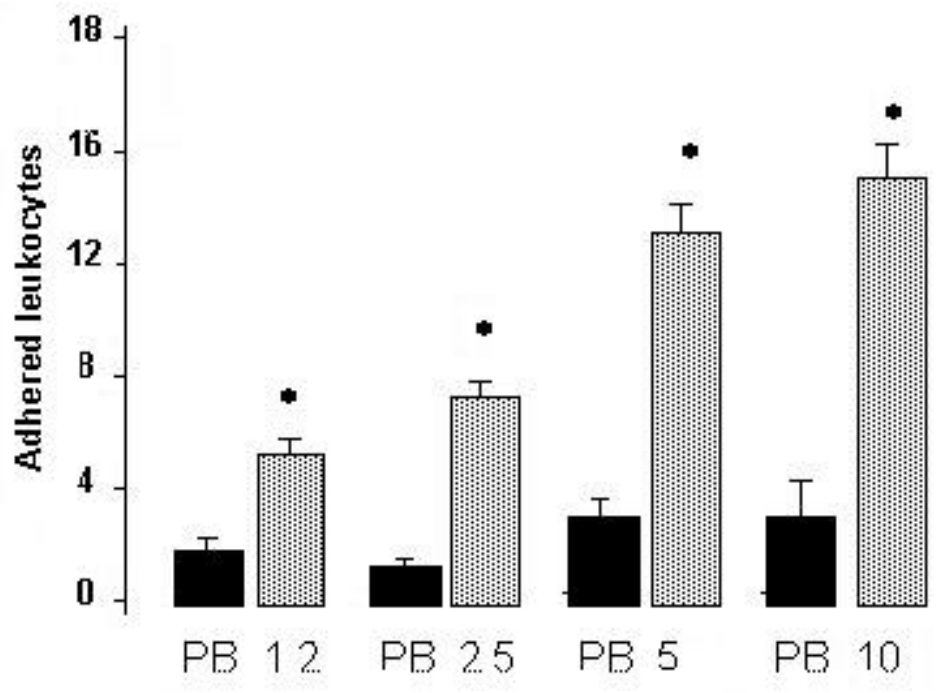

Topical application

Figure 4. Evaluation of rolling (A) and adherent (B) leukocytes induced by C-type lectin from Bothrops jararacussu venom. Samples $(30 \mu \mathrm{l})$ containing different doses of lectin were topically applied on the cremaster muscle of anesthetized mice. The aspect of pre and postcapillary venules was observed after 30min. * $p<0.05$, compared with control group.

(A)

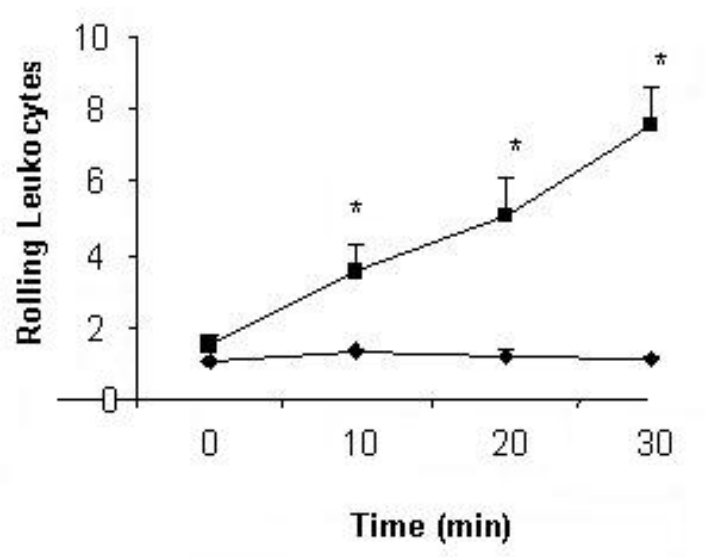

(B)

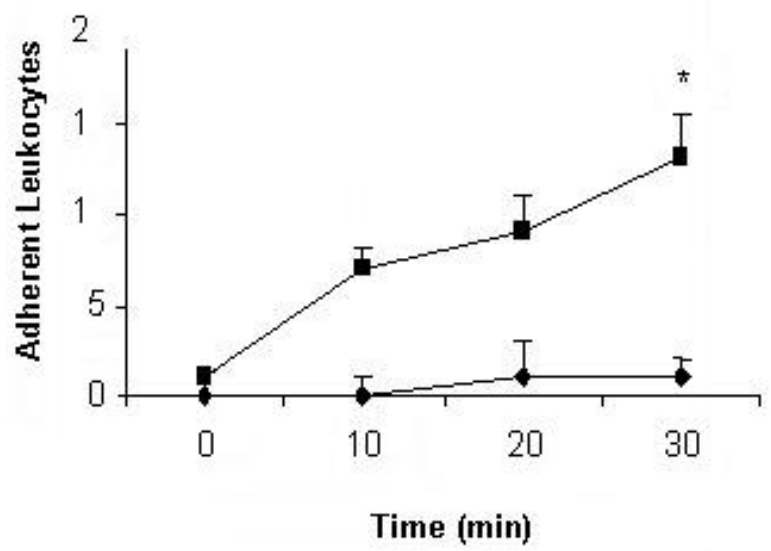

Time (min)

- PBS $\square$ Lectin $(5 \mu \mathrm{g})$ 
S. L. Elífio-Esposito et al. A C-TYPE LECTIN FROM Bothrops jararacussu VENOM CAN ADHERE TO EXTRACELLULAR MATRIX PROTEINS AND INDUCE THE ROLLING OF LEUKOCYTES. J. Venom. Anim. Toxins incl. Trop. Dis., 2007, 13, 4, p. 793

(C)
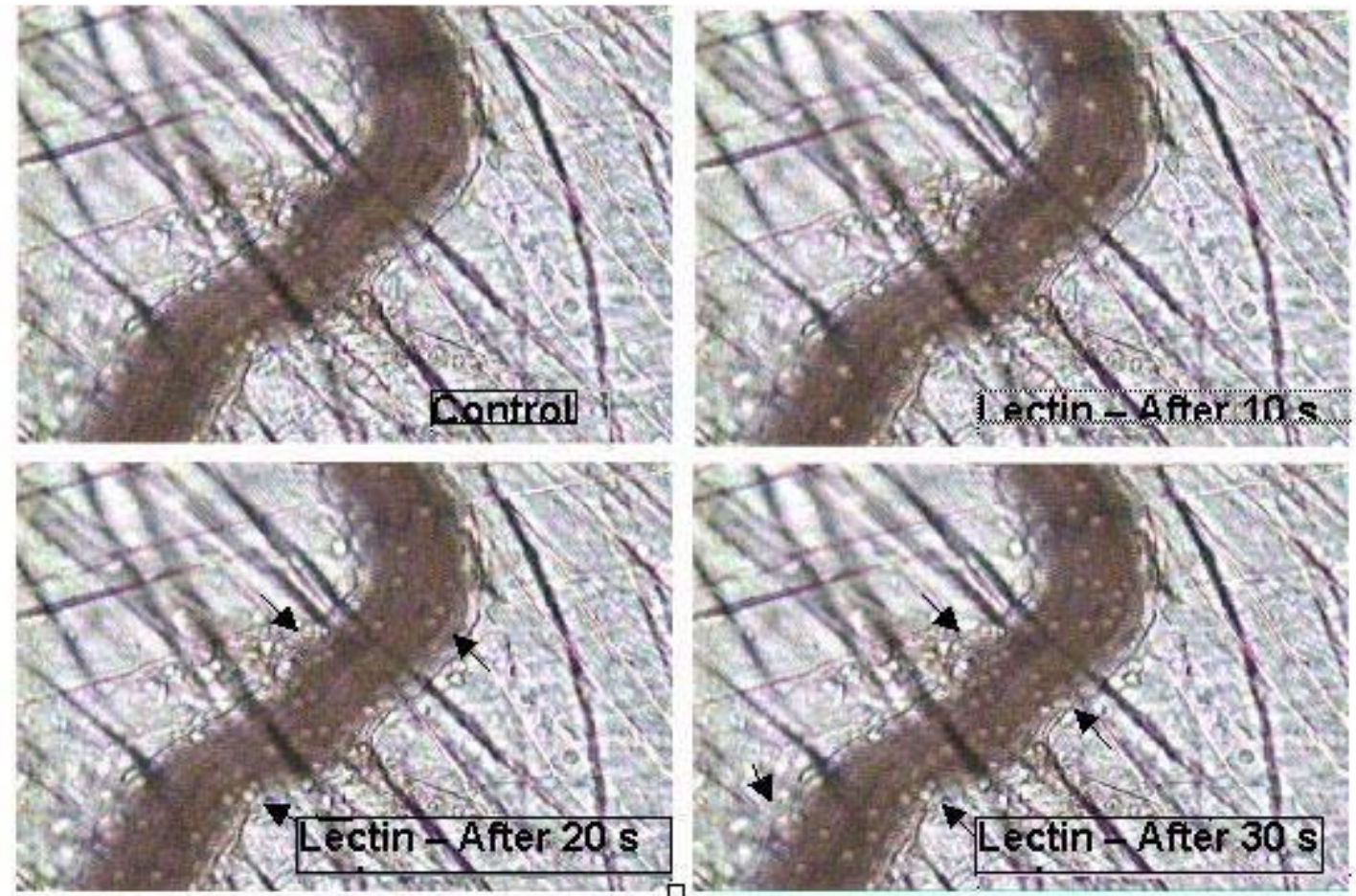

Figure 5. Evaluation of the kinectics of rolling and adherent leukocytes. Samples $(30 \mu \mathrm{l})$ containing $5 \mu \mathrm{g}$ lectin were topically applied on the cremaster muscle of anesthetized mice. The aspect of pre and postcapillary venules was observed every $10 \mathrm{~min}$ during $30 \mathrm{~min}$ and rolling $(A)$ and adhesion $(B)$ were recorded during $1 \mathrm{~min}$. The photos represent an intravital micrograph of cremaster muscle after 0, 10, 20 and 30s of topical application of lectin (C). Arrowheads indicate adhered leukocytes. ${ }^{*} p<0.05$, compared with control group.

\section{DISCUSSION}

Thrombolectin was the first lectin isolated from snake venom. It was discovered in the venom of Bothrops atrox and identified as a $\beta$-galactoside-binding dimeric lectin of $\mathrm{Mr}$ 28000 , similar in certain aspects to other $\mathrm{Ca}^{2+}$-dependent (C-type lectins; CTL) $\beta$ galactoside-binding lectins of vertebrates (12). Soon after, hemagglutinins from different snake venoms were discovered and characterized as a large family of structurally homologous proteins. These are dimers of $\sim 30 \mathrm{kDa}$, composed of similar disulfide-linked monomers with the CTL motif presenting saccharide-binding activity (14).

BjcuL is a typical component of this group of molecules. Its purification was first described by Carvalho et al. (4) using D-galactose affinity chromatography with $0.9 \%$ 
S. L. Elífio-Esposito et al. A C-TYPE LECTIN FROM Bothrops jararacussu VENOM CAN ADHERE TO EXTRACELLULAR MATRIX PROTEINS AND INDUCE THE ROLLING OF LEUKOCYTES. J. Venom. Anim. Toxins incl. Trop. Dis., 2007, 13, 4, p. 794

yield. Panunto et al. (29) isolated the lectin using a non-derivatized Sepharose 4-B column and obtained a similar result. Our modification of the former method consisted in a $4 \mathrm{~h}$ agitation period at $4^{\circ} \mathrm{C}$ prior to elution, which allowed an $\sim 5 \%$ yield. Apparently, it permitted a better interaction between the venom-pool lectin molecules and the gel matrix. The result of MALDI-TOF confirmed the purity of the carbohydrate-free fraction: carbohydrate might have been present because of an inefficient dialysis step or as column debris. Furthermore, this result confirms the expected molecular weight of BjcuL monomers of $\sim 16 \mathrm{kDa}(3)$. The amount of recovered lectin is consistent with the analysis of $B$. jararacussu venom gland transcriptome, which showed transcripts related to C-type lectin proteins to an order of $5 \%(17)$.

BjcuL can adhere, although weakly, to human metastatic breast cancer and human ovarian carcinoma cell lines, suppressing the viability of these tumor cells (5). However, considering its action in envenomation, few speculations were presented. BjcuL has been shown to be capable of producing edema and briefly increasing vascular permeability in mouse hind paws (29), which are signs of inflammatory processes. Extravasation of immune cells from peripheral blood through the vascular endothelium into the ECM is also a common event in inflammatory manifestations. We evaluated the cellular infiltration induced by lectin and our results, using intravital microscopy, show that the lectin acts directly on endothelial cells of postcapillary venules, creating an adhesive surface for the rolling of a great number of leukocytes. Neutrophil influx induced by ip injection of $B$. jararaca venom into mice has been shown to be related to the expression of adhesion molecules, responsible for rolling, firm adhesion, and transmigration events associated with neutrophil migration (33). Molecules in venom responsible for these effects have not been described yet, but it is possible to anticipate that lectins are involved, as lectin-carbohydrate interactions in leukocyte recruitment into inflammatory sites have become more evident (1). Galectin-3 is chemotactic in humans, promoting adhesion of neutrophils as well as other cell types to ECM proteins in an integrin-dependent manner $(19,23)$. This bridging of neutrophils to ECM due to galectin-3 appears to involve activation of the cells via $\mathrm{Ca}^{2+}$ and $\mathrm{Mg}^{2+}$-dependent processes. Ganiko and collaborators $(10,11)$ suggested that the interaction of a D-mannose-binding lectin $(\mathrm{KM}+)$, also known as 
S. L. Elífio-Esposito et al. A C-TYPE LECTIN FROM Bothrops jararacussu VENOM CAN ADHERE TO EXTRACELLULAR MATRIX PROTEINS AND INDUCE THE ROLLING OF LEUKOCYTES. J. Venom. Anim. Toxins incl. Trop. Dis., 2007, 13, 4, p. 795

artocarpin, with laminin, fibronectin and heparin makes possible the establishment and maintenance of a $\mathrm{KM}+$ molecular gradient, a necessary phenomenon to induce the directed movement of neutrophils.

Here, we showed the interaction of BjcuL with ECM components and evaluated the dependence of the carbohydrate recognition domain (CRD) in the interaction of BjcuL with fibronectin and vitronectin. Snake venom lectins are known to bind mostly to galactose and also to mannose (34). However, our results demonstrated that lectin pre-incubated with $100 \mathrm{mM}$ D-galactose had its interaction capacity reduced by about $20 \%$, whereas its incubation with $100 \mathrm{mM}$ D-mannose did not give rise to any alteration. These results reinforce the hypothesis that CRDs are involved in the inductive activity of migration (30) as well as the galactoside-binding preference of BjcuL.

Hemagglutination assays were carried out in order to analyze the integrity of the purified BjcuL as well as to establish the optimum conditions for biological studies. Our results indicated the requirement for divalent cations other than $\mathrm{Ca}^{2+}$, such as $\mathrm{Mg}^{2+}$, besides physiological conditions of $\mathrm{pH}$ and temperature for a better binding activity, which was expected, as the venom must act on mammalian preys.

In conclusion, we demonstrated a further characterization of BjcuL with respect to its hemaglutinating activity, which can be increased at neutral $\mathrm{pH}$ and temperature around $37^{\circ} \mathrm{C}$, in the presence of $\mathrm{Mg}^{2+}$, as a replacement for $\mathrm{Ca}^{2+}$. We showed that BjcuL can adhere to fibronocetin and vitronectin and act directly on endothelial cells of postcapillary venules, creating an adhesive surface for the rolling of a great number of leukocytes. However, to consider its participation in inflammation events, further investigation on its effect over leukocytes is needed.

\section{ACKNOWLEDGEMENTS}

We thank Butantan Institute for providing B. jararacussu venom, Nuno M. Domingues (Brazilian Center for Protein Sequencing, University of Brasilia) for MALDI-TOF analyses, and Dr. Silvio Sanches Veiga for the glycoproteins. This research was supported by grants from Araucária Foundation, Paraná State, and PUCPR, Brazil. 
S. L. Elifio-Esposito et al. A C-TYPE LECTIN FROM Bothrops jararacussu VENOM CAN ADHERE TO EXTRACELLULAR MATRIX PROTEINS AND INDUCE THE ROLLING OF LEUKOCYTES. J. Venom. Anim. Toxins incl. Trop. Dis., 2007, 13, 4, p. 796

Dr. M. Lopes-Ferreira is supported by The State of São Paulo Research Foundation (FAPESP).

\section{REFERENCES}

1 BUTCHER EC. Leukocyte-endothelial cell recognition-three (or more) steps to specificity and diversity. Cell., 1991, 67, 1033-6.

2 CAMPBELL JA., LAMAR WW. The venomous reptiles of Latin America. Ithaca; London: Comstok Publ. Assoc., 1989, 425.

3 CARVALHO DD., MARANGONI S., NOVELLO JC. Primary structure characterization of Bothrops jararacussu snake venom lectin. J. Prot. Chem., 2002, 21, 43-50.

4 CARVALHO DD., MARANGONI S., OLIVEIRA B., NOVELLO JC. Isolation and characterization of a new lectin from the venom of the snake Bothrops jararacussu. Rev. Biochem. Mol. Biol. Intern., 1998, 44, 933-8.

5 CARVALHO DD., SCHMITMEIER S., NOVELLO JC., MARKLAND FS. Effect of BJcuL (a lectin from the venom of the snake Bothrops jararacussu) on adhesion and growth of tumor and endothelial cells. Toxicon, 2001, 39, 1471-6.

6 DECLAUX C., DELACOURT C., D`ORTHO MP., BOYER V., LAFUMA C., HARF A. Role of gelatinase $B$ and elastase in human polymorphonuclear neutrophil migration across basement membrane. Am. J. Respir. Cell. Mol. Biol., 1996, 14, 288-95.

7 DUBOIS M., GILLES KA., HAMILTON JK., REBERS PA., SMITH F. Colorimetric method for determination of sugars and related substances. Anal. Chem., 1956, 28, 350-6.

8 FARSKY SHP., CRUZ JWMC., CURY Y., TEIXEIRA CFP. Leukocyte response induced by Bothrops jararaca crude venom: in vivo and in vitro studies. Toxicon, 1997, 35, 185-93.

9 FLORES CA., ZAPPELLINI A., PRADO-FRANCESCHI J. Lipoxygenase-derived mediators may be involved in in vivo neutrophil migration induced by Bothrops erythromelas and Bothrops alternatus venoms. Toxicon, 1993, 31, 1551-9.

10 GANIKO L. Neutrophil haptotaxis induced by the lectin KM+. Glycoconj. J., 1998, $15,527-30$. 
S. L. Elifio-Esposito et al. A C-TYPE LECTIN FROM Bothrops jararacussu VENOM CAN ADHERE TO EXTRACELLULAR MATRIX PROTEINS AND INDUCE THE ROLLING OF LEUKOCYTES. J. Venom. Anim. Toxins incl. Trop. Dis., 2007, 13, 4, p. 797

11 GANIKO L., MARTINS AR., FREYMULLER E., MORTARA RA., ROQUEBARREIRA M-C. Lectin KM+-induced neutrophil haptotaxis involves binding to laminin. Biochim. Biophys. Acta, 2005, 1721, 152-63.

12 GARTNER TK., OLGIVIE ML. Isolation and characterization of three $\mathrm{Ca}^{2+}$ dependent b-galactoside-specific lectins from snake venoms. Biochem. J., 1984, 224, 301-7.

13 GOLDSTEIN IJ., HUGHES RC., MONSIGNY M., OSAWA T., SHARON N. What should be called a lectin? Nature, 1980, 285, 66.

14 GUIMARÃES-GOMES V., OLIVEIRA-CARVALHO AL., JUNQUEIRA-DEAZEVEDO IL., DUTRA DLS., PUJOL-LUZ M., CASTRO HC., HO PL., ZINGALI RB. Cloning, characterization and structural analysis of a C-type lectin from Bothrops insularis (BiL) venom. Arch. Biochem. Biophys., 2004, 432, 1-11.

15 GUTIÉRREZ JM., LOMONTE B. Local tissue damage induced by Bothrops snake venoms. Mem. Inst. Butantan, 1989, 51, 211-23.

16 HAVT A., TOYAMA MH., NASCIMENTO NRFD., TOYAMA DO., NOBRE ACL., MARTINS AMC., BARBOSA PSF., NOVELLO JC., BOSCHERO AC., CARNEIRO EM., FONTELLES MC., MONTEIRO HSA. A new C-type animal lectin isolated from Bothrops pirajai is responsible for the snake venom major effects in the isolated kidney. Intern. J. Biochem. Cell Biol., 2005, 37, 130-41.

17 KASHIMA S., ROBERTO PG., SOARES AM., ASTOLFI-FILHO S., PEREIRA JO., GIULIATI S., FARIA JÚNIOR M., XAVIER MAS., FONTES MRM., GIGLIO JR., FRANÇA SC. Analysis of Bothrops jararacussu venomous gland transcriptome focusing on structural and functional aspects: I - gene expression profile of highly expressed phospholipases A2. Biochimie., 2004, 86, 211-9.

18 KLEIMAN HK., MCGARVEY ML., HASSEL JR., STAR VL., CANNON FB., LAURIE GW., MARTIN GR. Basement membrane complexes with biological activity. Biochemistry, 1986, 25, 312-8.

19 KUWABARA I., LIU FT. Galectin-3 promotes adhesion of human neutrophils to laminin. J. Immunol., 1996, 156, 3939-44.

20 LAEMMLI UK. Cleavage of structural proteins during the assembly of the head of bacteriophage T4. Nature, 1970, 227, 680-5. 
S. L. Elifio-Esposito et al. A C-TYPE LECTIN FROM Bothrops jararacussu VENOM CAN ADHERE TO EXTRACELLULAR MATRIX PROTEINS AND INDUCE THE ROLLING OF LEUKOCYTES. J. Venom. Anim. Toxins incl. Trop. Dis., $2007,13,4$, p. 798

21 LOWRY OH., ROSENBROUGH NJ., FARR IL., RANDALL RJ. Protein measurement with the Folin phenol reagent. J. Biol. Chem., 1951, 193, 265-75.

22 LU Q., NAVDAEV A., CLEMETSON JM., CLEMETSON KJ. Snake venom C-type lectins interacting with platelet receptors. Structure-function relationships and effects on haemostasis. Toxicon, 2005, 45, 1089-98.

23 MASSA SM., COOPER DN., LEFFLER H., BARONDES SH. L-29, an endogenous lectin, binds to glycoconjugate ligands with positive cooperativity. Biochemistry, 1993, 32, 260-7.

24 MASTRO AM., HURLEY DJ., WINNING RK., FILIPOWSKI R., OLGIVIE ML., GARTNER TK. Mitogenic activity of snake venom lectins. Cell. Tissue Kinet., 1986, 19, 557-66.

25 MILANI R., JORGE MT., FERRAZ DE CAMPOS FT., MARTINS FP., BOUSSO A., CARDOSO JLC., RIBEIRO LA., FAN HW., FRANÇA FOS., SANO-MARTINS IS., CARDOSO D., FERNANDEZ ICOF., FERNANDEZ JC., ALDRED VL., SANDOVAL MP., PUORTO G., THEAKSTON RDG., WARRELL DA. Snake bites by jararacuçu (Bothrops jararacussu): clinicopathological sudies of 29 proven cases in São Paulo State, Brazil. Q. J. Med., 1997, 90, 323-34.

26 MOURA-DA-SILVA AM., LAING GD., PAINE MJI., DENNISON JMTI., POLITI V., CRAMPTON JM., THEAKSTON RGD. Processing of pro-tumor necrosis factor-alpha by venom metalloproteinase: a hypothesis towards explaining local tissue damage following snake bite. Eur. J. Immunol., 1996, 26, 200-5.

27 NORMAN KE., KATOPODIS AG., THOMA G., KOLBINGER F., HICKS AE., COTTE MJ., POCKLEY AG., HELLEWELL PG. P-Selectin glycoprotein ligand-1 supports rolling on E- and P-selectin in vivo. Blood, 2000, 96, 3585-91.

28 OZEKI Y., MATSUI T., HAMAKO J., SUZUKI M., FUJIMURA Y., YOSHIDA E., NISHIDA S., TITANI K. C-type galactoside-binding lectin from Bothrops jararaca venom: comparison of its structure and function with those of Bothrocetin. Arch. Biochem. Biophys., 1994, 308, 306-10.

29 PANUNTO PC., SILVA MA., LINARDI A., BUZIN MP., MELO SE., MELLO SM., PRADO-FRANCESCHI J., HYSLOP S. Biological activities of a lectin from Bothrops jararacussu snake venom. Toxicon, 2006, 47, 21-31. 
S. L. Elífio-Esposito et al. A C-TYPE LECTIN FROM Bothrops jararacussu VENOM CAN ADHERE TO EXTRACELLULAR MATRIX PROTEINS AND INDUCE THE ROLLING OF LEUKOCYTES. J. Venom. Anim. Toxins incl. Trop. Dis., 2007, 13, 4, p. 799

30 SANTOS-DE-OLIVEIRA R., DIAS-BARUFFI M., THOMAZ SMO., BELTRAMINI LM., ROQUE-BARREIRA MC. Neutrophil migration-inducing lectin from Artocarpus integrifolia. J. Immunol., 1994, 153, 1798-807.

31 SPERANDIO M., SMITH ML., FORLOW SB., OLSON TS., XIA L., MCEVER RP., LEY K. P-selectin glycoprotein ligand-1 mediates L-selectin-dependent leukocyte rolling in venules. J. Exp. Med., 2003, 197, 1355-63.

32 YATOHGO T., IZUMI M., KASHIWAGI H., HAYASHI M. Novel purification of vitronectin from human plasma by heparin affinity chromatography. Cell Struct Funct., $1988,13,281-92$.

33 ZAMUNER SR., TEIXEIRA CFP. Cell adhesion molecules involved in the leukocyte recruitment induced by venom of the snake Bothrops jararaca. Mediators Inflamm., 2002, 11, 351-57.

34 ZHA HG., LEE WH., ZHANG Y. Cloning of cDNA encoding C-type lectins form Elapidae snakes Bungarus fasciatus and Bungarus multicinctus. Toxicon, 2001, 39, 1887-92. 